\title{
SUPLEMENTASI TEPUNG PORANG (Amorphophallus muelleri Blume) SEBAGAI Nutraceutical DALAM MANAJEMEN DIABETES MELLITUS TIPE 2
}

\author{
Nurlaili Susanti \\ Program Pasca Sarjana Univesitas Brawijaya \\ Email; dr.santie@gmail.com
}

\begin{abstract}
ABSTRAK
Diabetes is a group of metabolic diseases characterized by hyperglycemia. Type 2 Diabetes is most commonly type which accounts for 90-95\% of those, resulting from defects in insulin secretion and insulin action. Management of type 2 diabetes should combine pharmacological therapy with both diet modification and increasing physical activity. Nutraceutical was known to have important role. A kind of Araceae family, Porang (Amorphophallus muelleri Blume), has a main content of glucomannan. Glucomannan is a water-soluble polysaccharide, high fibers and low calories. Various studies suggest the benefit effects of glucomannan in type 2 diabetes mellitus to improve blood glucose level and lipid profiles. Its mechanism is postulated to be associated with the intrinsic physical effects of soluble fiber in the gastrointestinal tract and fermentation by microflora in the large intestine that trigger production of several gut hormones. Short Chain Fatty Acids, product of fiber fermentation, can improve insulin sensitivity through competition with free fatty acids and increasing expression of GLUT 4 in insulin sensitive tissues. Therefore, glucomannan from Porang has a great potential to be a nutraceutical for the management of type 2 diabetes mellitus.
\end{abstract}

Kata Kunci : Diabetes Mellitus, Porang, Glukomanan, Nutraceutical.

\section{Pendahuluan}

Diabetes Mellitus (DM) merupakan penyakit metabolik yang diderita oleh sekitar 382 juta penduduk di seluruh dunia pada tahun 2013, dan diperkirakan jumlahnya akan meningkat menjadi 592 juta pada tahun 2035. Peningkatan penderita DM terutama di negara berkembang, sebanyak 3 kasus baru setiap 10 detik atau kurang lebih 10 juta kasus baru setiap tahun. Angka mortalitas akibat DM sangat tinggi, sekitar 5,1 juta kematian pada tahun 2013 atau 1 orang meninggal setiap 6 detik. DM juga menguras anggaran kesehatan dunia sekurang-kurangnya USD 548 milyar dolar pada tahun 2013 (Internasional Diabetes Federation, 2013).

$$
\text { Terapi farmakologi dalam }
$$

manajemen DM tipe 2 senantiasa berkembang, akan tetapi mayoritas penderita DM tidak mampu mencapai tujuan terapi yang telah ditetapkan oleh American Diabetes Association yaitu kadar HbA1c<7\% (Bastaki, 2005). Manajemen Diabetes Mellitus seharusnya melibatkan kombinasi diet dan perubahan gaya hidup, terutama penderita DM tipe 2 yang disertai obesitas. Penelitian akhir-akhir ini mendukung bahwa nutraceutical memiliki peranan penting dalam manajemen Diabetes Mellitus tipe 2.

Umbi Porang (Amorphophallus muelleri Blume) memiliki kandungan glukomanan tinggi yang merupakan serat larut air. Serat larut air diketahui memiliki efek pada homeostasis glukosa, metabolisme lipid, dan asupan kalori. Makalah ini akan membahas mengenai 
potensi suplementasi tepung porang dalam manajemen DM tipe 2.

\section{Diabetes Mellitus}

DM merupakan kelompok penyakit metabolik yang ditandai oleh hiperglikemia sebagai akibat adanya gangguan dalam sekresi insulin, kerja insulin atau keduanya. (American Diabetes Association, 2013). Insulin merupakan hormon yang diproduksi di pankreas yang menjadikan glukosa dari makanan dapat masuk ke dalam sel untuk diubah menjadi energi yang dibutuhkan oleh tubuh. Penderita diabetes tidak dapat mengabsorbsi glukosa dengan cukup, sehingga glukosa menumpuk di darah menyebabkan hiperglikemia (International Diabetes Federation, 2013). Hiperglikemia kronis dihubungkan dengan disfungsi dan kerusakan beberapa organ seperti mata, ginjal, syaraf, jantung dan pembuluh darah (American Diabetes Association, 2013).

Ada 3 (tiga) tipe DM berdasarkan etiologi yang mendasarinya, yaitu DM tipe 1, DM tipe 2 dan DM gestasional. Pada DM Tipe 1, tubuh tidak mampu memproduksi insulin sehingga dibutuhkan injeksi insulin setiap hari. DM tipe 1 disebabkan oleh destruksi autoimun terhadap sel beta pancreas (Loghmani E, 2005). DM gestasional terjadi pada wanita yang mengalami resistensi insulin dan hiperglikemia selama kehamilan. Kondisi ini dihubungkan dengan adanya hambatan kerja insulin akibat hormon yang diproduksi oleh plasenta (Internasional Diabetes Federation, 2013).

DM Tipe 2 merupakan tipe paling umum yang diderita oleh sekitar 90-95\% penderita DM. Tipe ini ditandai oleh ketidakmampuan tubuh untuk memproduksi insulin dalam jumlah yang cukup dan terjadinya gangguan kerja insulin. DM tipe 2 disebabkan oleh adanya resistensi insulin di liver dan otot, peningkatan produksi glukosa di liver, kelebihan produksi asam lemak bebas oleh sel adiposa dan terjadinya defisiensi insulin relatif. Sekresi insulin menurun secara gradual mengikuti kerusakan sel beta pankreas (Loghmani E, 2005).

Jumlah penderita DM tipe 2 meningkat dengan cepat dihubungkan dengan perbaikan status ekonomi, penuaan, peningkatan urbanisasi, perubahan gaya hidup dan penurunan aktivitas fisik (International Diabetes Federation, 2013). Penderita DM tipe 2 umumnya mengalami obesitas yang dihubungkan dengan terjadinya resistensi insulin. Sedangkan pada penderita yang kurus, DM tipe 2 dihubungkan dengan peningkatan persentase distribusi lemak khususnya di area perut (American Diabetes Association, 2013).

Penatalaksanaan DM tipe 2 tidak membutuhkan insulin secara mutlak. Resistensi insulin dapat diperbaiki melalui penurunan berat badan dan terapi farmakologi untuk menurunkan kadar gula darah serta ditunjang dengan pengaturan diet sehat dan peningkatan aktivitas fisik (American Diabetes Association, 2013). Apabila modifikasi gaya hidup dan peningkatan aktivitas fisik tidak mampu mengontrol kadar gula darah, maka dibutuhkan intervensi terapi farmakologi. Tujuan penggunaan terapi farmakologi adalah untuk memperbaiki gangguan metabolik yang mendasari seperti resistensi insulin dan sekresi insulin yang tidak adekuat (Pandey et al., 2011).

Ada 5 (lima) golongan obat oral anti diabetes yaitu sulfonilurea, biguanid, alfaglukosidase inhibitor, tiazolidinedion, dan meglitinida. Obat-obatan ini memiliki efek samping yang beragam seperti sulfonilurea menyebabkan hipoglikemia dan peningkatan berat badan yang dihubungkan dengan hiperinsulinemia, biguanid menyebabkan kelemahan dan asidosis laktat, alfa glukosidase inhibitor menyebabkan diare, sedangkan tiazolidinedion menyebabkan peningkatan kadar kolesterol LDL (Bastaki, 2005). Obat-obatan oral anti diabetes juga memicu terjadinya resistensi dan responnya berkurang pada populasi tertentu. Selain itu 
penggunaannya juga tidak aman selama kehamilan (Ogamba, 2014).

\section{Nutraceutical dalam Manajemen Diabetes Mellitus Tipe 2}

Istilah nutraceutical pertama kali dikenalkan oleh Stephen DeFelice, pendiri dan ketua Foundation for Innovation in Medicine (FIM) pada akhir tahun 1989. Istilah ini berasal dari kata nutrition yang berarti makanan dan pharmaceutical yang berarti obat. Nutraceutical didefinisikan sebagai makanan yang memiliki efek baik bagi kesehatan, mencakup pencegahan maupun pengobatan penyakit (Rajat el al., 2012).

Nutraceutical berbeda dengan makanan fungsional. Makanan fungsional adalah makanan yang disiapkan secara ilmiah dengan atau tanpa pengetahuan bagaimana atau mengapa makanan tersebut digunakan. Makanan fungsional memenuhi kebutuhan tubuh akan vitamin, lemak, protein, dan karbohidrat untuk mempertahankan kesehatan. Makanan fungsional yang digunakan dalam pencegahan dan/atau terapi penyakit dinamakan nutraceutical. Produk makanan yang digunakan sebagai nutraceutical diantaranya probiotik, prebiotik, makanan berserat, asam lemak omega 3, dan antioksidan (Pandey et al., 2010).

Nutraceutical memiliki efek yang menguntungkan dalam mengontrol DM karena dapat memperbaiki kadar glukosa darah dan sensitivitas insulin baik pada individu normal maupun DM tipe 2, dislipidemia, dan resistensi insulin. Nutraceutical yang berperan dalam manajemen diabetes mellitus dikelompokkan menjadi 3 (tiga) kategori yaitu nutrien, herbal, dan suplemen diet. Nutrien merupakan substansi dengan fungsi nutrisi yang telah diketahui seperti vitamin, mineral, asam amino, dan asam lemak. Herbal merupakan produk botani dalam bentuk konsentrat dan ekstrak. Sedangkan suplemen diet merupakan reagen yang didapat dari sumber lain seperti piruvat, kondroitin sulfat, dan prekursor hormon steroid yang memiliki fungsi khusus seperti nutrisi olah raga, suplemen penurun berat badan, dan pengganti makan (Pandey et al., 2011).

Sejumlah herbal diketahui berperan penting dalam pencegahan maupun penatalaksanaan diabetes mellitus. Mekanisme kerjanya melibatkan beberapa organ diantaranya liver, intestin, pankreas, jaringan adiposa, dan otot. Di liver, herbal bekerja dengan menurunkan produksi glukosa, di intestin herbal bekerja dengan menurunkan absorbsi glukosa, di pankreas herbal bekerja dengan meningkatkan sekresi insulin, sedangkan di jaringan adiposa dan otot herbal bekerja dengan meningkatkan ambilan glukosa dari organ perifer. Kondisi ini akan menyebabkan penurunan glukosa darah, peningkatan sekresi insulin sehingga lebih banyak glukosa yang dapat dimanfaatkan oleh jaringan untuk menghasilkan energi (Pandey et al., 2011).

\section{Umbi Porang (Amorphophallus muelleri Blume)}

Porang (Amorphophallus muelleri Blume) secara taksonomi tergolong dalam famili Araceae (Koswara, 2014). Tanaman ini tergolong semak berumbi yang tumbuh di dalam hutan. Batang tanaman ini tegak, lunak dan terdapat totol putih-hijau dengan tinggi berkisar $100-150 \mathrm{~cm}$. Daunnya menjari berpangkal 3, berwarna hijau dan mempunyai titik pangkal daun tempat tumbuhnya bulbil (umbi generatif). Bulbil mulai terlihat pada usia 2 bulan, berupa bintik gelap pada pangkal daun. Umbi Porang memiliki daging berwarna kuning cerah, berserat halus dan bergetah (PPPPI, 2013).

Setelah dipanen umbi porang kemudian diproses menjadi chip porang dengan cara diiris tipis kemudian dijemur dibawah matahari hingga kering. Chip porang kemudian diproses di dalam mesin penepung untuk menghasilkan tepung porang. Untuk memurnikan tepung porang dilakukan fraksinasi dan pencucian dengan etanol untuk meminimalisir kandungan 
kalsium oksalat dan zat pengotor lain sehingga kandungan yang tersisa sebagian besar adalah glukomanan (PPPPI, 2013).

Tepung porang yang telah dimurnikan dapat dimanfaatkan dalam industri, farmasi dan makanan. Pemanfaatan dalam industri diantaranya sebagai bahan pembuat lem, pelapis kedap air, dan perekat cat. Dalam industi farmasi, tepung porang dapat dimanfaatkan sebagai bahan pengikat dalam pembuatan tablet, pembungkus kapsul dan media pertumbuhan mikroba. Sedangkan pemanfaatan dalam industri makanan diantaranya sebagai zat pengental makanan, bahan pembuat konyaku (tahu jepang) dan shirataki (mie jepang), bahan campuran mie instan, pembuat daging vegetarian, serta bahan pengikat rasa pada bumbu penyedap (PPPPI, 2013 dan Koswara, 2014).

Kandungan umbi porang segar per 100 gram terdiri dari 83,3\% air, 3,58\% glukomanan, $7,65 \%$ pati, $0,92 \%$ protein, $0,02 \%$ lemak, 2,5\% serat berat, $1,22 \%$ abu, dan 0,19\% kalsium oksalat (Arifin, 2001). Kristal kalsium oksalat merupakan suatu produk buangan dari metabolisme sel yang sudah tidak digunakan lagi oleh tanaman. Kristal ini merupakan deposit dari proses-proses eleminasi zat-zat anorganik pada tumbuh-tumbuhan. Endapan anorganik ini dalam tumbuhan sebagian besar tersusun atas garam-garam kalsium dan anhidrat silica (Koswara, 2014). Kalsium oksalat menyebabkan rasa gatal dan iritasi saat dikonsumsi. Konsumsi jangka panjang dari makanan yang mengandung kalsium oksalat dapat menyebabkan kristalisasi di ginjal dan gangguan kesehatan lainnya (Arifin, 2001).

Kandungan utama tepung porang adalah glukomanan. Glukomanan merupakan polisakarida larut air yang tersusun atas D-glucose $(\mathrm{G})$ dan Dmannoses (M) dengan rasio molar G:M sekitar 1:1.6. Glukomanan memiliki kandungan serat yang tinggi, rendah kalori dan bersifat hidrokoloid yang khas (Gao et al, 2004). Glukomanan memiliki percabangan beta 1,4 dimana tidak dapat dicerna oleh amylase saliva dan pancreas, sehingga sampai di kolon banyak perubahan. Berat molekul glukomanan bervariasi antara 200.000 hingga 2.000.000 Dalton bergantung pada proses dan waktu penyimpanan. Glukomanan dapat mengabsorbsi hingga 50 kali beratnya dalam air (Keithley et al., 2005).

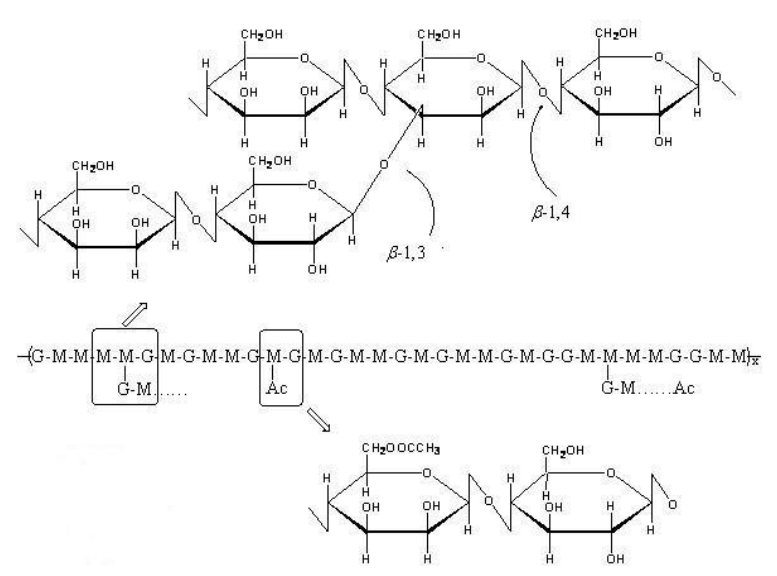

Gambar 1. Struktur polisakarida umbi porang (Gao et al, 2004)

\section{Hasil Penelitian Efek Glukomanan pada Subyek Normal dan Diabetes Mellitus Tipe 2}

Berbagai penelitian tentang manfaat porang pada diabetes mellitus tipe 2 telah banyak dilakukan oleh para ilmuwan, diantaranya penelitian yang dilakukan oleh Vuksan et al., pada tahun 2000 di Kanada. Sebanyak 11 orang direkrut dalam penelitian ini dengan kriteria inklusi yaitu toleransi glukosa terganggu, penurunan kolesterol HDL, peningkatan trigliserida, dan hipertensi sedang. Secara random, mereka diminta untuk memakan biskuit yang terbuat dari tepung mannan (8-13 g glukomanan/hari) atau biskuit yang terbuat dari tepung terigu sebagai kontrol selama 3 minggu. Kemudian diperiksa kadar kolesterol dan profil lipid dari serum. Diperoleh kesimpulan bahwa diet yang mengandung glukomanan dapat memperbaiki kontrol glikemik dan profil 
lipid sehingga dapat dijadikan terapi yang potensial bagi sindrom resistensi insulin.

\begin{tabular}{|c|c|c|c|c|c|c|c|c|}
\hline \multirow[b]{2}{*}{ Risk factor } & \multicolumn{3}{|c|}{$\mathrm{KJM}$} & \multicolumn{3}{|c|}{ WB-control } & \multicolumn{2}{|c|}{ Between treatments } \\
\hline & Week 0 & Week 3 & Change (\%) & Week 0 & Week 3 & Change (\%) & Change (\%) & $\mathrm{P}$ \\
\hline \multicolumn{9}{|l|}{ Cholesterol $(\mathrm{mmol} / \mathrm{l})$} \\
\hline Total & $6.2 \pm 0.3$ & $5.0 \pm 0.2$ & $-19 \pm 2.69^{*}$ & $6.0 \pm 0.2$ & $5.6 \pm 0.2$ & $-6.3 \pm 3.36$ & $-12.4 \pm 3.1$ & $0.0038^{*}$ \\
\hline LDL & $3.9 \pm 0.2$ & $2.8 \pm 0.2$ & $-29 \pm 3.37 *$ & $3.8 \pm 0.2$ & $3.5 \pm 0.2$ & $-6.6 \pm 5.04$ & $-22.3 \pm 3.9$ & $0.0017^{*}$ \\
\hline $\mathrm{HDL}$ & $1.0 \pm 0.1$ & $0.9 \pm 0.1$ & $-8.5 \pm 2.19^{*}$ & $1.0 \pm 0.1$ & $0.9 \pm 0.1$ & $-9.6 \pm 2.24^{*}$ & $1.2 \pm 2.2$ & 0.9812 \\
\hline Triglyceride $(\mathrm{mmol} / \mathrm{i})$ & $2.8 \pm 0.2$ & $3.0 \pm 0.2$ & $10.1 \pm 9.92$ & $2.9 \pm 0.4$ & $3.0 \pm 0.3$ & $12.1 \pm 14$ & $-1.6 \pm 10$ & 0.7317 \\
\hline \multicolumn{9}{|l|}{ Apolipoprotein (g/1) } \\
\hline Apo A-1 & $1.4 \pm 0.1$ & $1.4 \pm 0.1$ & $-6.5 \pm 2.46^{*}$ & $1.5 \pm 0.1$ & $1.4 \pm 0.1$ & $-4.8 \pm 3.38$ & $-1.8 \pm 3.1$ & 0.3622 \\
\hline Apo B & $1.6 \pm 0.1$ & $1.3 \pm 0.1$ & $-19 \pm 2.78^{*}$ & $1.6 \pm 0.1$ & $1.5 \pm 0.1$ & $-4.5 \pm 4.47$ & $-15.1 \pm 4.3$ & $0.0003^{*}$ \\
\hline \multicolumn{9}{|l|}{ Lipid ratios } \\
\hline Total/HDL cholesterol & $6.5 \pm 0.5$ & $5.7 \pm 0.4$ & $-11 \pm 3.02 *$ & $6.2 \pm 0.4$ & $6.4 \pm 0.5$ & $4.14 \pm 4.16$ & $-15.2 \pm 3.4$ & $0.0023^{*}$ \\
\hline Apo B/apo A-1 & $1.1 \pm 0.1$ & $1.0 \pm 0.1$ & $-13 \pm 3.02 *$ & $1.1 \pm 0.1$ & $1.1 \pm 0.1$ & $0.72 \pm 3.61$ & $-13.1 \pm 3.4$ & $0.0002^{*}$ \\
\hline LDL/HDL & $4.2 \pm 0.4$ & $3.2 \pm 0.3$ & $-22 \pm 3.72^{*}$ & $3.9 \pm 0.3$ & $3.9 \pm 0.4$ & $0.22 \pm 6.27$ & $-22.2 \pm 4.1$ & $0.0012^{*}$ \\
\hline \multicolumn{9}{|l|}{ Glycemic control } \\
\hline Glucose $(\mathrm{mmol} / \mathrm{i})$ & $6.8 \pm 0.5$ & $5.9 \pm 0.3$ & $-13 \pm 2.48^{*}$ & $6.6 \pm 0.3$ & $5.9 \pm 0.4$ & $-9.6 \pm 4.27$ & $-3.8 \pm 3.6$ & 0.7653 \\
\hline Fructosamine (mmol/li) & $286 \pm 13.6$ & $269 \pm 11.9$ & $-5.6 \pm 1.46^{*}$ & $279 \pm 11.7$ & $278 \pm 12.6$ & $-0.39 \pm 1.3$ & $-5.2 \pm 1.4$ & $0.0013^{*}$ \\
\hline Insulin $(\mathrm{pmol} / \mathrm{l})$ & $94.8 \pm 16.6$ & $91.1 \pm 16.5$ & $0.91 \pm 8.88$ & $99.2 \pm 16.5$ & $88.5 \pm 11.4$ & $-3.0 \pm 9.67$ & $3.9 \pm 8.9$ & 0.9683 \\
\hline \multicolumn{9}{|l|}{ Blood pressure $\left(\mathrm{mmH}_{\mathrm{g}}\right)$} \\
\hline Systolic & $139 \pm 2.0$ & $135 \pm 3.6$ & $-2.9 \pm 1.88$ & $135 \pm 2.6$ & $138 \pm 3.7$ & $2.2 \pm 2.5$ & $-5.1 \pm 2.2$ & 0.448 \\
\hline Diastolic & $85.4 \pm 1.8$ & $84.8 \pm 1.5$ & $-0.26 \pm 2.55$ & $85.5 \pm 1.7$ & $86.5 \pm 1.5$ & $1.33 \pm 1.49$ & $-1.4 \pm 2.1$ & 0.2647 \\
\hline Body weight $(\mathrm{kg})$ & $80.7 \pm 5.1$ & $80.6 \pm 5$ & $-0.17 \pm 0.14$ & $81 \pm 5.3$ & $80.6 \pm 5.1$ & $-0.29 \pm 0.35$ & $0.1 \pm 0.2$ & 0.5303 \\
\hline
\end{tabular}

Gambar 2. Hasil penelitian efek diet tinggi serat dari Glukomanan pada sindrom resistensi insulin (Vuksan et al., 2000)

Penelitian crosssectional oleh Steemburgo pada tahun 2009 di Brazil yang melibatkan 214 pasien DM tipe 2 tanpa konseling diet 6 bulan sebelumnya. Asupan makanan dievaluasi selama 3 hari ke belakang. Hasil penelitian didapatkan data pasien dengan sindroma metabolik $(\mathrm{n}=$ 174) memiliki total asupan rendah (16,7 +$6,2$ vs $19,5+-6,5$ g/hari, $p=0,010)$ dan serat larut $(5,3+-1,8$ vs $6+-2,7 \mathrm{~g} / \mathrm{hari}, \mathrm{p}=$ $0,011)$ dibandingkan pasien tanpa sindroma metabolik. Penelitian ini menyimpulkan bahwa asupan serat larut air dari glukomanan diduga memiliki efek protektif terhadap sindroma metabolik pada pasien dengan DM tipe 2.

Penelitian in vivo pada tikus Diabetes Mellitus diinduksi dengan diet tinggi kolesterol dan streptozotosin dosis $35 \mathrm{mg} / \mathrm{kg}$ BB secara intravena serta diberi suplementasi diet $15 \%$ glukomanan. Didapatkan penurunan kadar glukosa darah dan lipoprotein yang mendukung bahwa asupan tinggi serat dari glukomanan dapat mencegah pembentukan atheroma pada tikus DM (Hozumi et al., 1995).

Penelitian Doi di Jepang dilakukan pada 24 subyek normal dan 21 subyek DM yang diberikan diet 3,9 gram glukomanan didapatkan hasil rerata kadar glukosa darah pada subyek yang mendapat suplemen glukomanan menurun secara signifikan dibandingkan kontrol pada menit ke-90 $(85.9+-4.9 \mathrm{mg} / \mathrm{dl}$ dibandingkan $112.2+$ $11.7 \mathrm{mg} / \mathrm{dl}, \mathrm{p}<0.05)$. Pada tes toleransi glukosa subyek normal didapatkan rerata kadar glukosa darah menurun secara signifikan dibandingkan kontrol pada menit ke 30, 60, 120 dan 180. Kadar insulin serum juga menurun secara signifikan dibandingkan kontrol pada menit ke 30, 60, dan 90. Sedangkan tes toleransi glukosa yang dilakukan pada subyek dengan DM tipe 2 didapatka rerata kadar glukosa darah menurun secara signifikan dibandingkan kontrol subyek normal pada menit ke 30 dan 60. 


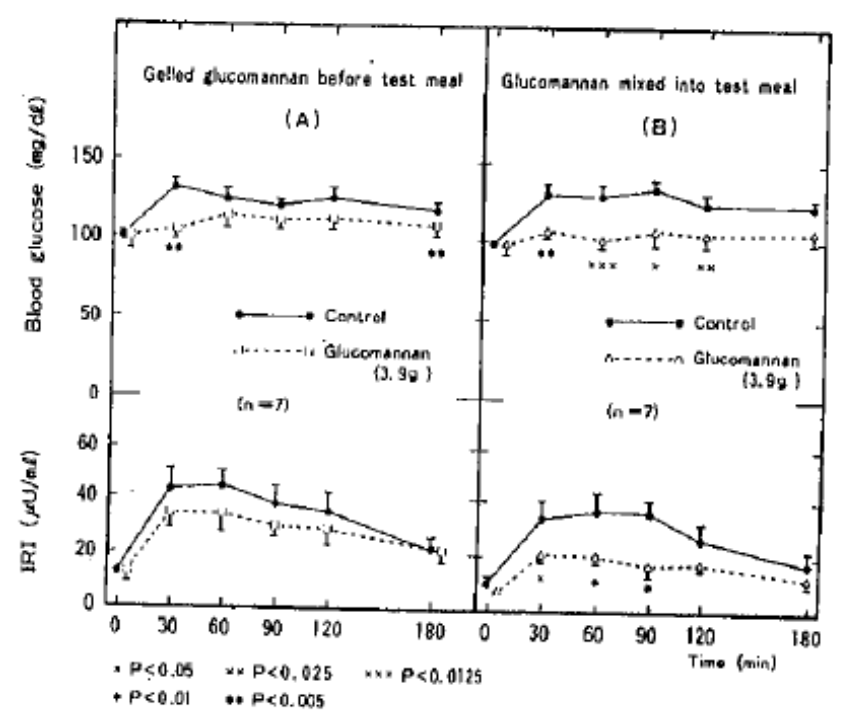

Gambar 3. Efek glukomanan pada kadar glukosa darah dan insulin subyek normal (Doi, 1981)

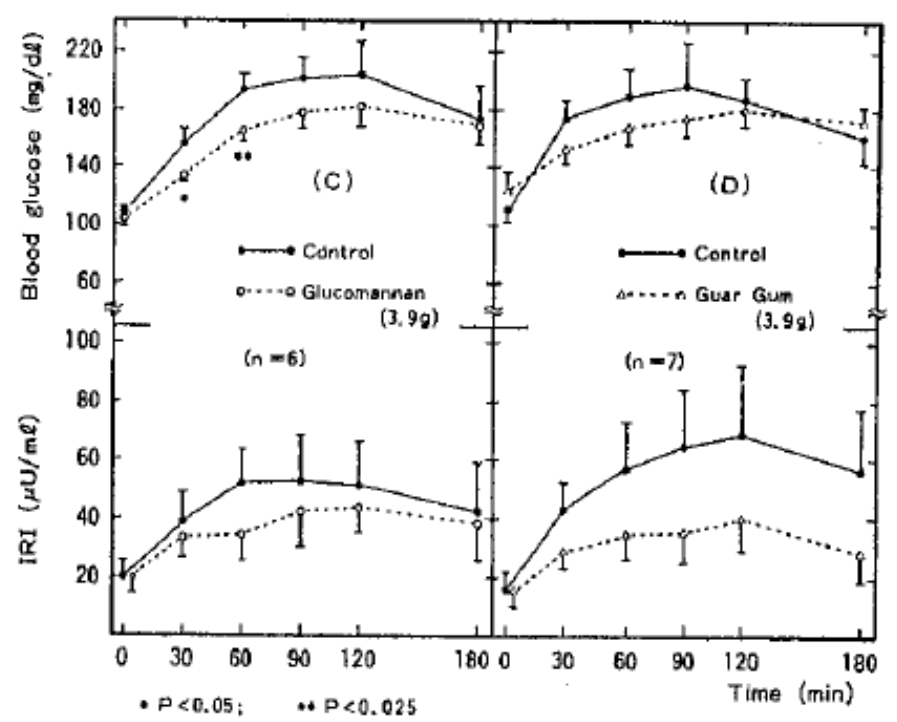

Gambar 4. Efek glukomanan pada kadar glukosa darah dan insulin subyek dengan DM tipe 2 (Doi, 1981)

\section{Mekanisme Potensial Glukomanan Sebagai Nutraceutical dalam Manajemen Diabetes Mellitus Tipe 2 \\ Mekanisme kerja glukomanan} dihubungkan dengan beberapa literatur ilmiah yang mendokumentasikan efek makanan berserat pada homeostasis glukosa, metabolisme lipid dan asupan kalori. Serat dapat menginduksi rasa kenyang yang lebih besar dibandingkan polisakarida lain melalui efek fisik intrinsik serat diantaranya dapat menggumpal, membentuk gel, mengubah viskositas isi lambung, memodulasi fungsi motorik lambung dan memperbaiki kadar glukosa pospandrial dan respon insulin. Kondisi ini akan menyebabkan keterlambatan pengosongan lambung, modifikasi aktivitas mioelektrik gastrointestinal, memperlambat waktu transit di usus besar, menurunnya difusi glukosa melalui lapisan yang kedap air, serta menurunnya kontak dengan enzim pencernaan alfa-amilase. Serat juga memiliki energi yang rendah sehingga dapat menurunkan asupan kalori (Papathanasopoulos dan Camilleri, 2010).

Serat larut air akan membentuk gel kental yang dapat melewati pencernaan di 
usus halus dan dapat dengan mudah difermentasi oleh mikroflora di usus besar. Fermentasi serat larut air diduga dapat memicu produksi Glucagon Like Peptide (GLP-1) dan peptide YY. Peptida YY merupakan hormon usus yang berperan dalam menginduksi rasa kenyang, sedangkan GLP-1 adalah hormone inkretin yang dapat menstimulasi pelepasan insulin oleh sel beta pancreas. Fermentasi serat larut air akan menghasilkan asam lemak rantai pendek (Short Chain Fatty Acid, $S C F A)$ seperti asetat, propionate, dan butirat. SCFA akan berkompetisi dengan asam lemak bebas (Free Fatty Acid, FFA) (Lattimer dan Haub, 2010).

Peningkatan SCFA juga akan menurunkan produksi glukosa hepar dan memperbaiki homeostasis lipid. G Protein Coupled reseptor (GPR-41) dan GPR-43 merupakan target langsung dari SCFA. SCFA menstimulasi adipogenesis melalui GPR43. Serat larut air dihubungkan dengan tingginya adiponektin plasma yang merupakan sinyal starvasi perifer yang dapat memicu penyimpanan trigliserida di jaringan adiposa sehingga menurunkan akumulasinya di liver dan otot skelet dan memperbaiki sensitivitas insulin (Weickert dan Pfeiffer, 2008).

Serat larut air juga mempengaruhi mekanisme ambilan glukosa perifer melalui peningkatan ekspresi GLUT 4 yang meningkatkan ambilan glukosa di otot skelet, memperbaiki sensitivitas insulin dan menormalkan kadar glukosa darah (Cameron-Smith et al., 1997 dan Song et al., 2000). SCFA juga meningkatkan ekspresi PPAR gamma yang meregulasi ekspresi GLUT 4 di jaringan adiposa (Park et al., 1998).

\section{Kesimpulan}

Dari kajian diatas dapat disimpulkan bahwa Glukomanan yang terkandung dalam tepung porang (Amorphophallus muelleri Blume) memiliki peluang menjadi nutraceutical dalam manajemen Diabetes Mellitus Tipe 2. Penelitian lebih lanjut dibutuhkan untuk menentukan dosis optimal yang digunakan dalam terapi, meningkatkan aspek keamanannya dengan menurunkan kadar kalsium oksalat, serta mengkaji mekanisme molekuler yang mendasari efek glukomanan dalam menurunkan kadar glukosa darah.

\section{Daftar Pustaka}

American Diabetes Association, 2013. Diagnosis and Classification of Diabetes Mellitus. Diabetes Care. Vol 36. Supp 1. p s67-s744.

Arifin, M. A. 2001. Pengeringan Kripik Umbi Iles-iles secara mekanik untuk meningkatkan mutu keripik iles-iles. Thesis. Teknologi Pasca Panen. PPS. IPB.

Bastaki S, 2005. Diabetes mellitus and its treatment. Int. J. Diabet. Metab. Vol 13. p 111-134.

Cameron-Smith D, Habito R, Barnett M, Collier, G. 1997. Dietary guar gum improves insulin sensitivity in streptozotocin-induced diabetic rats. J Nutr. Vol 127. p 359-364.

Doi, K. 1981. Effect of glucomannan (konjac fiber) on glucose and lipid metabolism in normal and diabetic subjects. Proceeding of the third symposium International congress series No 549. Honolulu.

Gao S J, Nishinari K. Effect of deacetylation rate on gelation kinetics of konjac glucomannan. Colloids and Surfaces B: Biointerfaces.2004, 38, 241-249.

Hozumi, T. Yoshida, M. Ishida, Y. Mimoto, H. Sawa, J. Doi, K. Kazumi, T. 1995. Longterm effects of dietary fiber supplementation on serum glucose and lipoprotein levels in diabetic rats fed a high cholesterol diet. Endocrine journal. vol 42 (2). p 187-192.

International Diabetes Federation, 2013. IDF Diabetes Atlas. Sixth edition.

Keithley, J dan Swanson, B. 2005. Glucomannan and obesity : a 
Critical review. Alternative therapies. Vol 11. No 6. p30-34.

Koswasra, 2014. Modul Teknologi Pengolahan Umbi-umbian. Bagian 2

: Pengolahan Umbi Porang. Southeast Asian Food And Agricultural Science and technology (SEAFAST) Center. Institut Pertanian Bogor

Lattimer, J dan Haub, M. 2010. Effects of dietary fiber and its components on metabolic health. Nutrients. Vol 2. p 1266-1289.

Loghmani, E. 2005. Diabetes Mellitus : type 1 and type 2 . Guidelines for adolescent nutrition services. Online. Available at http://www.epi.umn.edu/let/pubs/ad ol_book.shtm. p 167-182.

Ogamba J, Ifediba E, Ughachukwu P, 2014. Nutraceutical in the manajement of type-2 diabetes mellitus. Peak Journal of Medicine and Medical Science. Vol 2 (2). p 10-18.

Pandey M, Verma R, Saraf S, 2010. Nutraceuticals : new era of medicine and health. Asian Journal of Pharmaceutical and Clinical Research. Vol 3 (1). p 11-15.

Pandey, M dan Vijayakumar. 2011. Nutraceutical supplementation for diabetes : a review. international journal of pharmacy and pharmaceutical sciences. Vol 3 . Suppl 4. p 33-40.

Papathanasopoulos, A dan Camilleri, M. 2010. Dietary fiber supplements : effects in obesity and metabolic syndrome and relationship to gastrointestinal functions. Gastroenterology. Vol 138. No. 1. p 65-72.

Park, KS. Ciaraldi, TP. Abrams-Carter, L. Mudaliar, S. Nikoulina, SE. Henry, RR. 1998. Troglitazone effects on gene expression in human skeletal muscle of type II diabetes involve up-regulation of peroxisome proliferator-activated receptor- gamma. J Clin Endocrinol Metab. Vol 83. p2830-2835.

PPPPI, 2013. Budidaya dan Pengembangan Porang (Amorphophallus muelleri Blume) sebagai salah satu potensi bahan baku lokal. Modul diseminasi. Universitas Brawijaya. Malang.

Rajat S, Manisha S, Robin R, Sunil K, 2012. Nutraceuticals : a Review. International Research Journal of Pharmacy. Vol 3 (4). p 95-99.

Song, YJ. Sawamura, M. Ikeda, K. 2000. Soluble dietary fibre improves insulin sensitivity by increasing muscle GLUT-4 content in strokeprone spontaneously hypertensive rats. Clin Exp Pharmacol Physiol. Vol 27. p41-45.

Steemburgo, T. Dall'Alba, V. Almeida, JC. Zelmanovitz, T. Gross, JL. de Azevedo, MJ. 2009. Intake of soluble fibers has a protective role for the presence of metabolic syndrome in patients with type 2 diabetes. European journal of clinical nutrition. Vol 62. p 127133.

Vuksan, V., Sievenpiper JL., Owen, R., Swilley JA., Spadafora, P., Jenkins, DJA., Vidgen, E., Brighenti, F., Josse, RG., Leiter, LA., Xu, Z., and Novokmwt, R. 2000. Beneficial effects of viscous dietary fiber from konjac-mannan in subjects with the insulin resistance syndrome. Diabetes Care. Vol 23. No 1. p 914.

Weickert, M dan Pfeiffer, A. 2008. Metabolic effects of dietary fiber consumption and prevention of diabetes. The Journal of Nutrition. Vol 138. p 439-442. 